\title{
Different Characteristics of Social Networks for COVID-19 in Europe
}

\author{
SEUNGIL YUM \\ Construction, and Planning, University of Florida, Gainesville, USA. \\ Email: yumseungil@ufl.edu
}

\begin{abstract}
This study sheds new light on the different characteristics of social networks for COVID-19 in European regions. This study explores six countries (the United Kingdom, Spain, Italy, Germany, France, and Sweden) by employing social network analysis for Twitter. First, this study finds that European countries show different characteristics for social networks with regard to COVID-19. For example, the UK has only national key players, France shows a majority of national key players, and other countries have all global key players. Donald Trump played an important role in the social networks of Italy, Germany and Sweden while he was the US president. Second, European countries demonstrate different social networks for groups. For example, the UK shows the most active communications across groups, whereas Germany shows the least communication networks across groups. Lastly, European countries reveal highly different interests regarding COVID-19. For example, the UK is more interested in the epidemic and vaccines, Germany focuses on schools and studies, and Sweden cares more about herd immunity and lockdown.
\end{abstract}

\section{Introduction}

Coronavirus (COVID-19) is one of the worst catastrophes across the world since 2019. As of 19 July 2020, about 14 million cases of COVID-19 and 0.6 million deaths have been reported across more than 188 countries. Developing COVID-19 policies has become an essential task for governments and decision makers to protect their citizen and the economy (see, for example, S. Chen et al., 2020; Fang et al., 2020; Hale et al., 2020; Lin et al., 2020; Sebastiani et al., 2020).

Countries and governments have put a lot of effort into protecting the public from the COVID-19 pandemic and into developing recovery plans (see, for example, Cao et al., 2020; Collaborative et al., 2020; Ramanathan et al., 2020; Shaker et al., 2020; Shoenfeld, 2020). For example, the European Council (2020) reports that EU leaders agreed on an overall budget of $€ 1.824$ trillion for 2021-2027, combining the 
multiannual financial framework (MFF) and an extraordinary recovery effort, and Next Generation EU (NGEU) to support EU citizens from the economic downturn caused by the COVID-19 pandemic.

Scholars have examined how COVID-19 plays an important role in human welfare and economic status (see, for example, Brodin, 2020; Jandrić, 2020; Le et al., 2020; Liu et al., 2020; Shereen et al., 2020). For instance, Hollander and Carr (2020) highlight that an estimated basic reproduction number (R0) of 2.2 means that each infected person spreads the infection to an additional two persons, and so the outbreak will continue to spread until the reproduction number falls below 1.0. Fernandes (2020) reports that French GDP was previously forecasted to grow by $1.2 \%$ in 2020 , whereas the estimated growth rate is $-2 \%$ when taking into account the economic impact of the crisis.

However, prior studies have barely investigated how people communicate with each other to get information on COVID-19 in order to cope with the ongoing pandemic (see, for example, Bonaccorsi et al., 2020; Borges do Nascimento et al., 2020; Campbell, 2020; Chakraborty and Maity, 2020; Oliver et al., 2020). For instance, Karami et al. (2021) employ frequency analysis to find highly frequent manifestations and therapeutic chemicals based on 9298 papers representing COVID-19 research. Understanding communication networks is very important, since governments and centres for disease control could provide valuable information about COVID-19 and spread government policies in a timely manner. In addition, previous articles have barely explored how people have different online networks according to the different countries in which they reside. We can assume that people have different communication systems according to their race, society, culture, and geography. Therefore, the research question of this study is how do people have different social networks for COVID-19 according to their countries?

To answer the question, this study explores the social networks for COVID-19 across countries by employing Social Network Analysis (SNA) for Twitter, which is one of the most popular Social Network Services (SNS). This study explores the social networks for COVID-19 in six European countries: the United Kingdom (UK), Spain, Italy, Germany, France, and Sweden (in descending order by patient numbers in Europe as of 19 July 2020) (see Table 1). To the best of the author's knowledge, this is the first article exploring social networks with respect to COVID-19 for SNS across European regions.

\section{Literature Review}

COVID-19 is a new disease caused by a strain of coronavirus. COVID-19 was first identified in December 2019 in Wuhan, China, and has become an ongoing global pandemic. The World Health Organization (WHO) declared the outbreak a Public Health Emergency of International Concern on 30 January 2020 and a pandemic on 11 March 2020. 
Table 1. COVID-19 in Europe as of July 19, 2020

\begin{tabular}{lrccr}
\hline \hline Location & Confirmed & Cases per 1M people & Recovered & Deaths \\
\hline United Kingdom & 294,803 & 4437 & - & 45,318 \\
Spain & 258,855 & 5496 & - & 28,416 \\
Italy & 243,967 & 4050 & 132,282 & 35,028 \\
Germany & 201,372 & 2422 & - & 9083 \\
France & 173,304 & 2584 & - & 30,120 \\
Sweden & 77,281 & 7479 & - & 5619 \\
Worldwide & $14,060,402$ & 1808 & $7,861,823$ & 601,820 \\
\hline \hline
\end{tabular}

Source: Google news

The COVID-19 pandemic has had significant effects on European countries. As of 13 March 2020, when the number of new COVID-19 patients became greater than those in China, WHO considered Europe to be the active centre of the COVID-19 pandemic. As of 17 March 2020, all countries within Europe had confirmed cases of COVID-19. Among European countries, six countries (the UK, Spain, Italy, Germany, France, and Sweden) have experienced the most severe damage from COVID-19. According to the European Centre for Disease Prevention and Control. (2020a), as of 19 July 2020, 1,620,084 cases have been reported in the EU/EEA and the UK: United Kingdom (294,066), Spain (260,255), Italy (244,216), Germany (201,574), France $(174,674)$, Sweden (77,281). In addition, 180,524 deaths have been reported in the EU/EEA and the UK: United Kingdom (45,273), Italy (35,042), France $(30,152)$, Spain $(28,420)$, Germany $(9,084)$, and Sweden $(5,619)$.

Many organizations and centres for disease control have tried their best to minimize the damage caused by COVID-19. For instance, the European Centre for Disease Prevention and Control (ECDC) (2020b) releases a weekly COVID-19 surveillance report, which presents the epidemiological characteristics of COVID-19 cases reported to the European Surveillance System (TESSy) and assesses the quality of the data. ECDC (2020) also releases a Communicable Disease Threats Report every week, which covers COVID-19, to help epidemiologists and health professionals reduce active public health threats.

Many scholars have also attempted to highlight how COVID-19 is severely affecting human welfare and environments in Europe (see, for example, Flaxman et al., 2020; Kinross et al., 2020; Lechien et al., 2020). For instance, Lechien et al. (2020) reported that 263 female patients of COVID-19 from 12 European hospitals experienced coughs, myalgia, and loss of appetite the most. Flaxman et al. (2020) show that major non-pharmaceutical interventions have had a large effect on reducing transmission across 11 European countries for the period from the start of the COVID-19 epidemic until 4 May 2020. Kinross et al. (2020) highlight that the number of COVID-19 patients is sharply increasing in the European regions. The observed trends in the cumulative COVID-19 cases reveal that the COVID19 pandemic is progressing at a comparable speed in all European countries. 
Koch et al. (2021) show that public institutions have a substantial demand for IT jobs in the public sector labour market in Germany.

On the other hand, SNA (Social Network Analyses) based on big data have become some of the most important tools in the academic field. Many scholars have employed SNA to understand how social networks play an important role in coping with the COVID-19 pandemic (see, for example, Nielsen et al., 2021; Rufai and Bunce, 2020; Yum, 2020a). For example, Nielsen et al. (2021) report that superspreading sharply stimulates mitigations that reduce the overall personal contact number, and that social clustering increases this effect based on social network modulation. Yum (2020a) highlights that the US presidents, the World Health Organization (WHO) and its regional offices, Centers for Disease Control, and news channels play a significant role regarding news of COVID-19 in the US.

Some scholars criticize that SNA have weak theoretical contributions, but these can be further utilized for theoretical model development (see, for example, Grover et al., 2020; Kar and Dwivedi, 2020). For instance, methodological contributions of SNA contribute to developing theoretical models using social media data (see, for example, Grover et al., 2018; Kar, 2020). The findings of this study would explain more about how people respond differently to the COVID-19 pandemic according to their countries and groups, which could contribute to theory building in international information and health communication research. For example, the findings are expected to contribute towards communication and health literature, such as improving theoretical coverage, reducing interference of noise, improving validity and reliability of models, strengthening causality linkages, reducing methodological biases, and developing theory that works well within limitations (see, for example, Aguinis and Edwards, 2014; Kar and Dwivedi, 2020).

\section{Research Methodology}

This study employs Twitter, which is one of the most popular online platforms, to highlight the social networks with respect to COVID-19 in European regions. Social media have become research tools for scholars to understand how people get important news and information about COVID-19 (see, for example, Cinelli et al., 2020; Cuello-Garcia et al., 2020; Hussain, 2020). Among various social media, Twitter has been widely used for big data analyses in academic research (see, for example, ChowWhite et al., 2018; Gayo-Avello, 2013; Nambisan et al., 2015). For example, Chakraborty and Kar (2021) highlight a typology of COVID-19 impacts focused on the education sector based on user-generated content from Twitter.

This study employs SNA based on big data analyses for Twitter. In the health communication literature, government agencies around the world have enthusiastically utilized Twitter to deliver important news and information to the public in crisis situations (see, for example, Ahmad and Murad, 2020; Q. Chen et al., 2020; Gao et al., 2020). From the theoretical background of big data analyses, social media platforms can enhance the responsiveness of governments to communicate COVID-19 
information efficiently and effectively to their citizens (see, for example, Q. Chen et al., 2020; Li et al., 2020; Liao et al., 2020).

In addition, in recent years, SNA have been carried out using data collected from social interactions in online platforms (see, for example, Bonchi et al., 2011; Borgatti and Everett, 1992; Ennett et al., 2006; Mizruchi, 1994; Streeter and Gillespie, 1993). As SNA have been developed as a methodology for analysing social relations among people, governments can use SNA to play an important role in overcoming difficulties due to COVID-19 by exploring social network structures and important key players (see, for example, Burt, 1978; Block et al., 2020; Hung et al., 2020; Yum, 2020a).

To be specific, this study utilizes Twitter data to highlight the online communications of people about COVID-19 across key players such as the news media, politicians and organizations. This study observes the Twitter data stream between 13 July and 20 July 2020 based on the keywords 'COVID-19' and the various countries, and chooses the best data set for the analyses (18 July and 19 July) based on some important criteria (e.g. the number of Twitter users, communications, and suitable content).

This study employs NodeXL to highlight the social networks of European regions for COVID-19. NodeXL is a visualization software program that supports social networks and content analysis. NodeXL has been widely utilized to understand social network systems in academic fields (see, for example, Jagals and Van der Walt, 2016). This study employs the in-degree centrality to capture public key players for Twitter users (the explanation for in-degree centrality follows). This study chooses the top 10 key players among all Twitter users based on the magnitude of the indegree centrality (see Table 2 for descriptive statistics).

This study first calculates in-degree centrality, out-degree centrality, and closeness centrality to highlight social networks for COVID 19 in the European regions (see Figures 1-3). In-degree centrality measures the number of edges that point toward the vertex of interest. Out-degree centrality calculates the number of edges that the vertex of interest points toward (Hansen et al., 2010). Closeness centrality measures the reciprocal of the mean geodesic distance, which is the shortest path between a node and all other reachable nodes (Freeman, 1978).

Next, this article explores the top 10 key players in European regions (see Tables 3-8: Table 3: the UK; Table 4: Spain; Table 5: Italy; Table 6: Germany; Table 7: France; and Table 8: Sweden). This study employs cluster analysis by utilizing the Clauset-Newman-Moore cluster algorithm (see Figures 4 and 5). Cluster analysis is a methodology for the task of assigning a set of objects into groups so that the objects in the same cluster are more similar to each other than those in other clusters. The Clauset-Newman-Moore cluster algorithm finds clusters of nodes that link to each other more frequently than outside the cluster (see, for example, Shneiderman and Dunne, 2012). Figure 4 shows the social networks regarding COVID-19 for the typical case, and Figure 5 shows the social networks of six countries according to groups. This study considers hashtag analyses to understand people's interests in COVID-19 across countries. 
Table 2. Descriptive statistics

\begin{tabular}{|c|c|c|c|c|c|c|}
\hline Graph metric & UK & Spain & Italy & Germany & France & Sweden \\
\hline Graph type & Directed & Directed & Directed & Directed & Directed & Directed \\
\hline Vertices & 19,020 & 15,656 & 18,497 & 18,645 & 15,800 & 13,109 \\
\hline Unique edges & 28,613 & 17,853 & 21,918 & 19,161 & 20,206 & 16,170 \\
\hline Edges with duplicates & 4,648 & 1,861 & 1,551 & 330 & 3,279 & 1,739 \\
\hline Total edges & 33,261 & 19,714 & 23,469 & 19,491 & 23,485 & 17,909 \\
\hline Self-loops & 3,577 & 2,182 & 1,675 & 497 & 2,028 & 1,653 \\
\hline Reciprocated vertex pair ratio & 0.017 & 0.005 & 0.004 & 0.001 & 0.005 & 0.004 \\
\hline Reciprocated edge ratio & 0.033 & 0.010 & 0.008 & 0.002 & 0.010 & 0.009 \\
\hline Connected components & 2,821 & 1,810 & 1,633 & 563 & 1,358 & 1,426 \\
\hline Single-vertex connected components & 1,358 & 1,013 & 847 & 243 & 767 & 778 \\
\hline Maximum vertices in a connected component & 11,571 & 111,58 & 14,552 & 16,784 & 11,175 & 9,585 \\
\hline Maximum edges in a connected component & 23,522 & 14,118 & 18,992 & 17,338 & 18,075 & 14,313 \\
\hline Maximum geodesic distance (diameter) & 17 & 20 & 21 & 14 & 20 & 21 \\
\hline Average geodesic distance & 5.862 & 5.022 & 5.069 & 3.393 & 5.069 & 6.011 \\
\hline Graph density & 0.000 & 0.000 & 0.000 & 0.000 & 0.000 & 0.000 \\
\hline Modularity & 0.801 & 0.846 & 0.859 & 0.559 & 0.779 & 0.814 \\
\hline Minimum in-degree & 0 & 0 & 0 & 0 & 0 & 0 \\
\hline Maximum in-degree & 624 & 1,753 & 2,717 & 12,423 & 2,615 & 907 \\
\hline Average in-degree & 1.601 & 1.184 & 1.219 & 1.035 & 1.359 & 1.286 \\
\hline Median in-degree & 0 & 0 & 0 & 0 & 0 & 0 \\
\hline Minimum out-degree & 0 & 0 & 0 & 0 & 0 & 0 \\
\hline Maximum out-degree & 135 & 102 & 100 & 93 & 21 & 124 \\
\hline Average out-degree & 1.601 & 1.184 & 1.219 & 1.035 & 1.359 & 1.286 \\
\hline Median out-degree & 1 & 1 & 1 & 1 & 1 & 1 \\
\hline Minimum closeness centrality & 0 & 0 & 0 & 0 & 0 & 0 \\
\hline Maximum closeness centrality & 1 & 1 & 100 & 1 & 1 & 1 \\
\hline Average closeness centrality & 0.112 & 0.073 & 1.219 & 0.023 & 0.054 & 0.067 \\
\hline Median closeness centrality & 0.000 & 0.000 & 1.000 & 0.000 & 0.000 & 0.000 \\
\hline
\end{tabular}



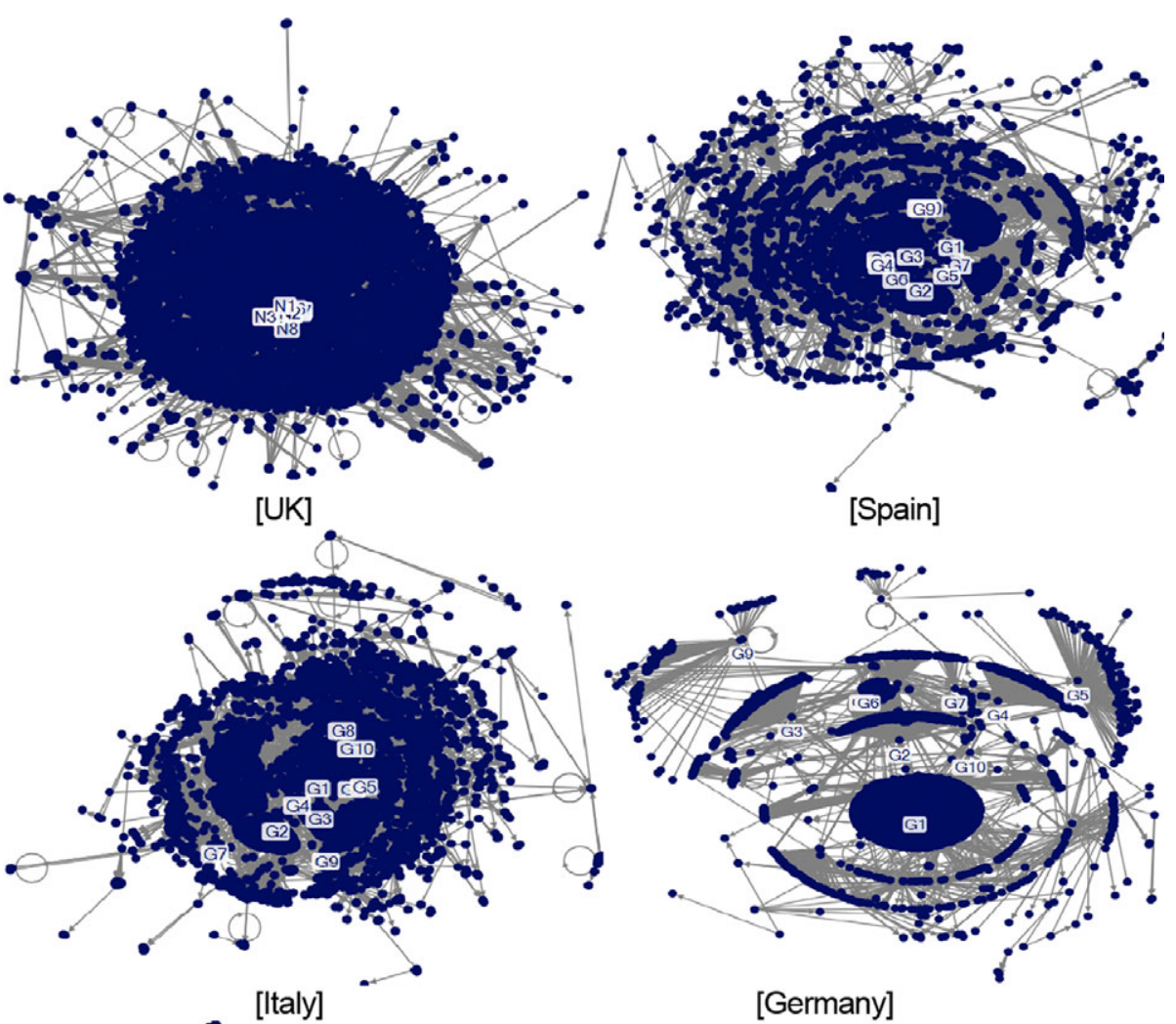

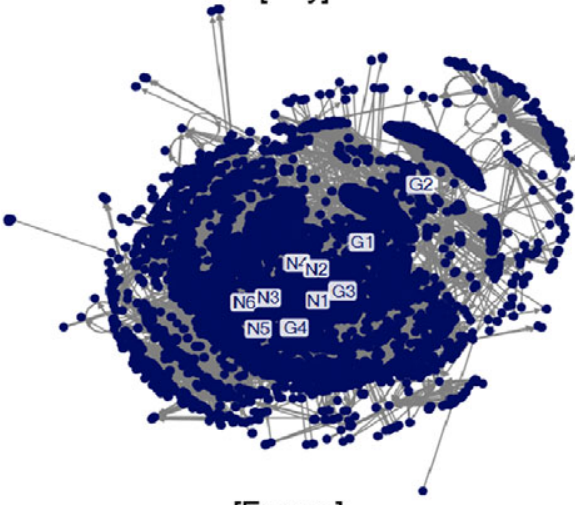

[France]
[Germany]

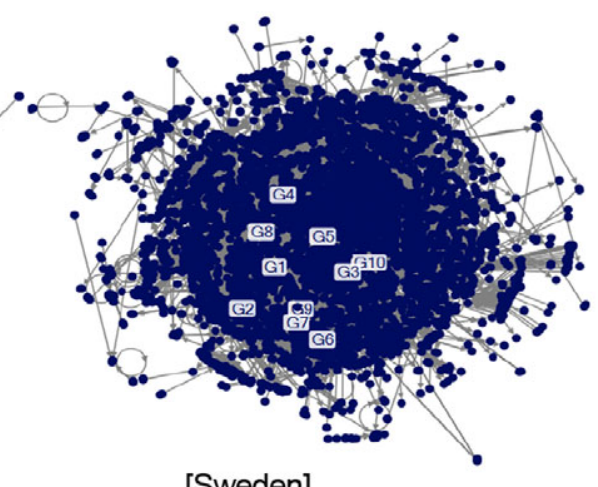

[Sweden]

Figure 1. In-degree centrality

Note: The higher number represents the higher in-degree centrality. For example, N1 has centrality higher than N2. See Tables 3-8 for the rank of in-degree centrality.

The findings of this article will highlight the social network structures and the top public key players with regard to COVID-19 according to countries and groups, based on a multitude of centrality types, cluster analyses, and hashtag analyses. This can help theory building for big data-driven and social network research. 

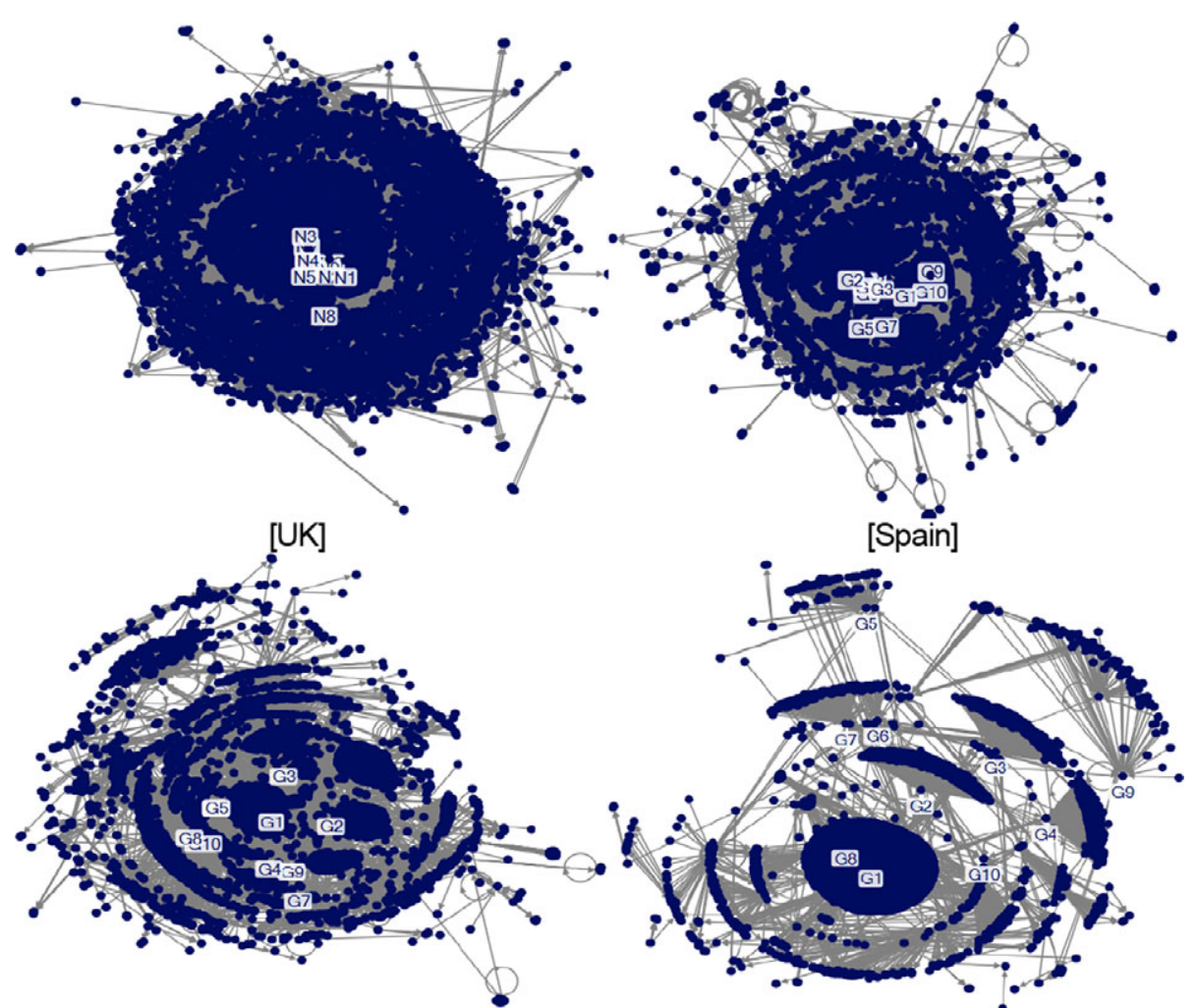

[ltaly]
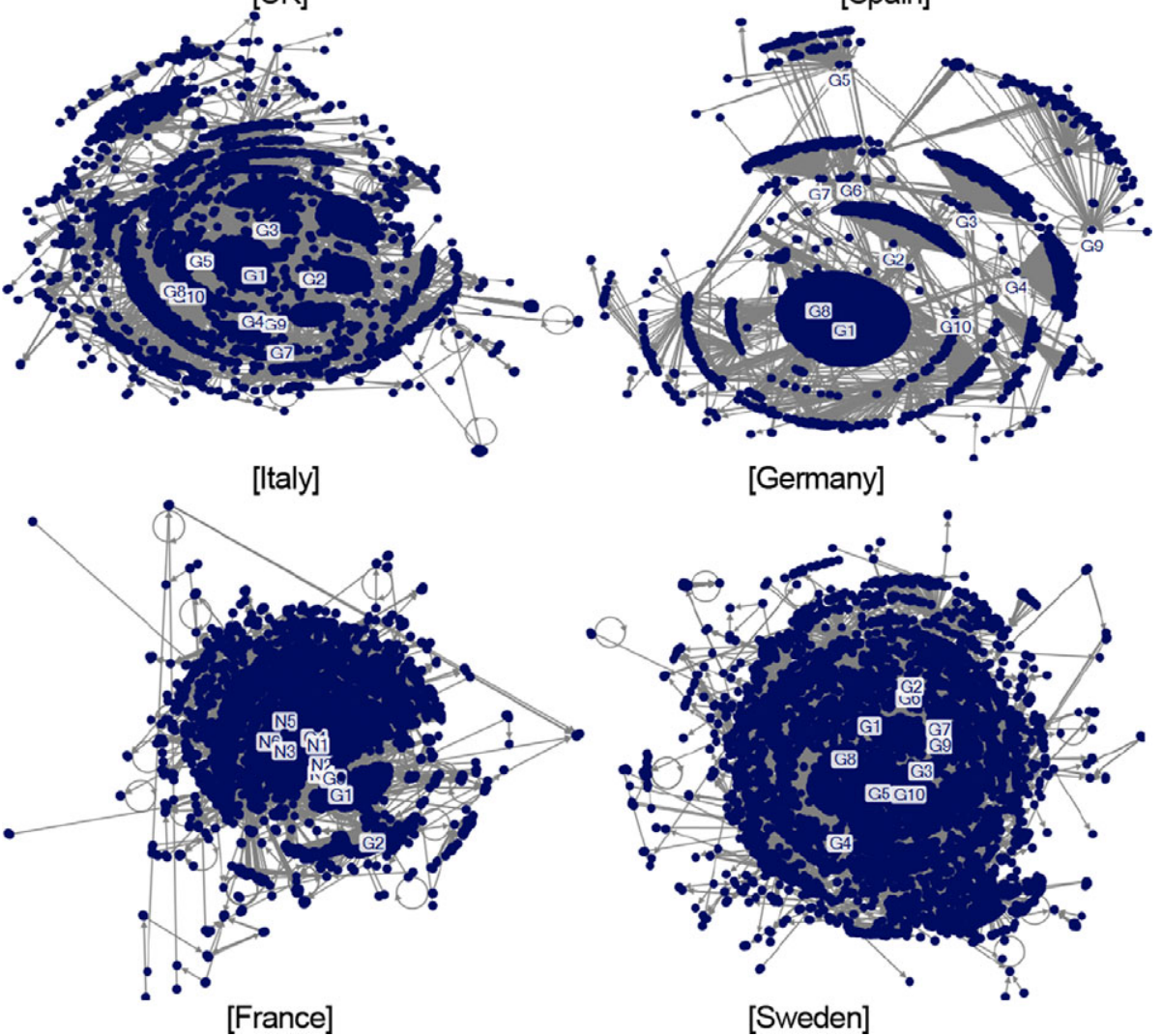

Figure 2. Out-degree centrality

\section{Results}

Figures 1-3. highlight that social networks for COVID-19 are differentiated by countries and centrality types (Figure 1: in-degree centrality, Figure 2: out-degree centrality, and Figure 3: closeness centrality). For instance, all key players in the UK are concentrated in the central part of the networks, whereas those of Germany are 

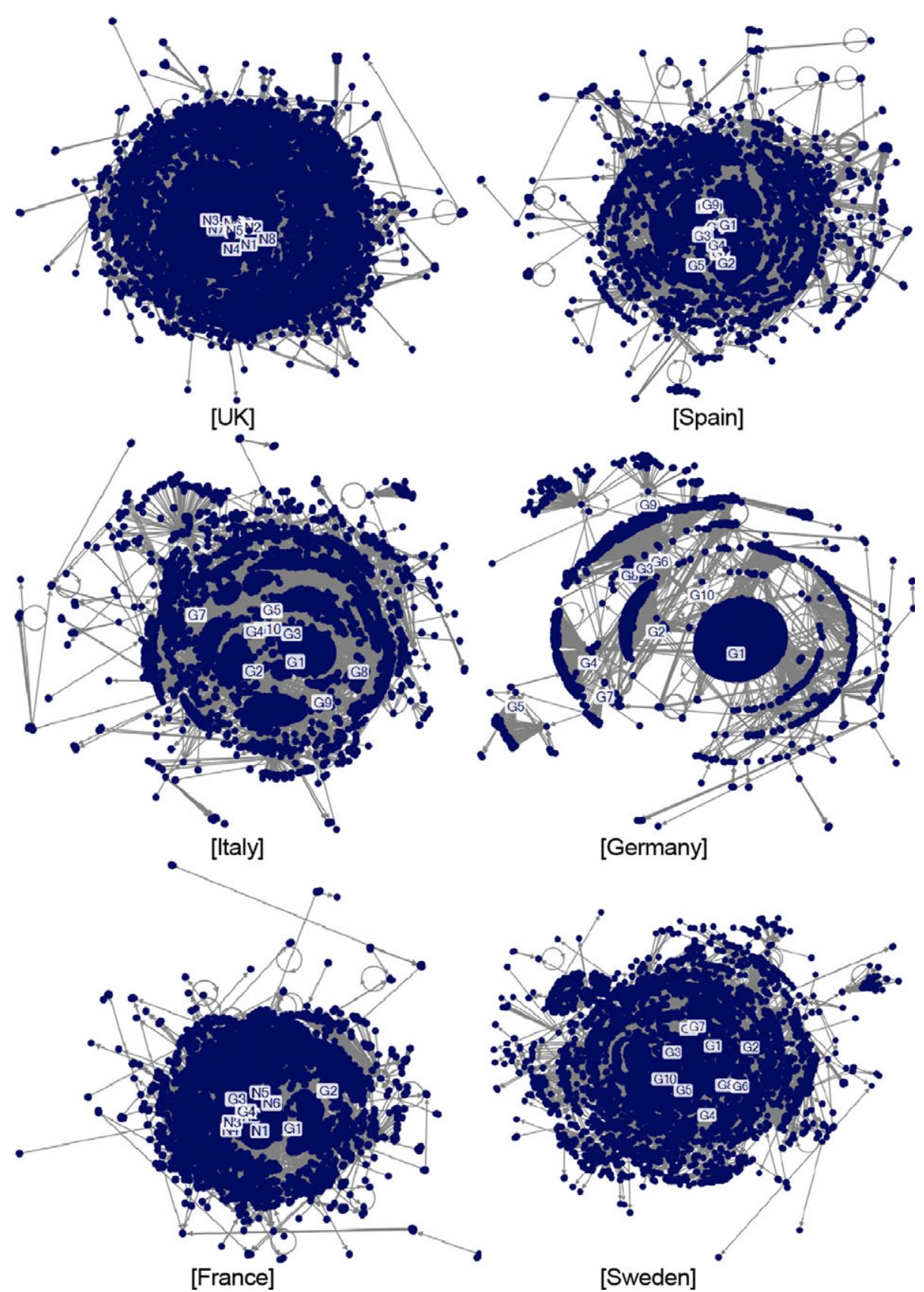

Figure 3. Closeness centrality

dispersed across the whole network in in-degree centrality (see Figure 1). In addition, all key players in the UK are located more in the central part of the networks in the in-degree centrality, whereas they are more distributed in the networks in the outdegree centrality (see Figures 1 and 2). 
Table 3. The top 10 key players in the UK

\begin{tabular}{|c|c|c|c|c|}
\hline & Label & ID & Name & Description \\
\hline 1 & N1 & 624 & The Telegraph & National British daily broadsheet newspaper \\
\hline 2 & $\mathrm{~N} 2$ & 457 & $\begin{array}{l}\text { Public Health } \\
\text { England }\end{array}$ & $\begin{array}{l}\text { Executive agency of the Department of Health and } \\
\text { Social Care in the UK }\end{array}$ \\
\hline 3 & N3 & 421 & Dominic Raab & Secretary of State for Foreign Affairs \\
\hline 4 & N4 & 367 & Philip Lee & $\begin{array}{l}\text { FY17 Doctor. Consultant Physician in Acute } \\
\text { Medicine and Medicine for the Elderly }\end{array}$ \\
\hline 5 & N5 & 319 & Jeremy Farrar & $\begin{array}{l}\text { British medical researcher and director of the } \\
\text { Wellcome Trust since } 2013\end{array}$ \\
\hline 6 & N6 & 269 & SkyNews & British free-to-air television news channel \\
\hline 7 & N7 & 210 & Daily Mail Online & British daily middle-market newspaper \\
\hline 8 & N8 & 204 & Yvette Cooper & $\begin{array}{l}\text { British Labour Party politician who has been the } \\
\text { Member of Parliament for Normanton, } \\
\text { Pontefract and Castleford }\end{array}$ \\
\hline 9 & N9 & 177 & $\begin{array}{l}\text { Office for National } \\
\text { Statistics (ONS) }\end{array}$ & Executive office of the UK Statistics Authority \\
\hline 10 & $\mathrm{~N} 10$ & 165 & Boris Johnson & Prime Minister of the United Kingdom \\
\hline
\end{tabular}

Note. ID: In-degree centrality, N: National key player, G: Global key player

In the UK networks, the most important characteristic is that the UK has all top 10 key players as national key players (see Table 3 ). The UK is the only country that has all national key players. This is the most different characteristic from other European countries, such as Spain, Italy, Germany, and Sweden, since they have all the top 10 key players as global key players. For example, The Telegraph, which is a national British daily broadsheet newspaper, ranks first. Public Health England, which is the executive agency of the Department of Health and Social Care in the UK, places second. Dominic Raab, who was the secretary of State for Foreign Affairs, takes third. Philip Lee, who is the doctor and consultant physician in acute medicine and medicine for the elderly ranks fourth. Jeremy Farrar who is the British medical researcher and director of the Wellcome Trust places fifth. Another remarkable characteristic is that the UK has many government key players in the top 10 . For example, government key players place second, third, eighth, ninth and tenth (second: Public Health England, third: Dominic Raab, eighth: Yvette Cooper, ninth: Office for National Statistics, and tenth: Boris Johnson).

Nodes are heavily concentrated in the central circle, and some nodes are widely dispersed around the circle. All key players are highly placed in the centre of the circle (see Figure 4). The UK shows the most active communications across groups (see Figure 5). In addition, the UK is the only country that has all top key players within group 10. The result shows that key players exert a pivotal impact on large groups in the UK. For instance, Public Health England (N2) and Boris Johnson (N10) play a significant role in group 1 . The finding highlights that government key players play a 
Table 4. The top 10 key players in Spain

\begin{tabular}{|c|c|c|c|c|}
\hline & Label & ID & Name & Description \\
\hline 1 & G1 & 1,753 & CNN International & $\begin{array}{l}\text { American news-based pay television channel } \\
\text { international }\end{array}$ \\
\hline 2 & G2 & 1,545 & The Spectator Index & $\begin{array}{l}\text { Online magazine website, offering analysis } \\
\text { and insight into the world's international } \\
\text { political, economic, scientific, cultural and } \\
\text { entertainment developments }\end{array}$ \\
\hline 3 & G3 & 1,040 & $\mathrm{CNN}$ & American news-based pay television channel \\
\hline 4 & G4 & 849 & Reuters & International news organization \\
\hline 5 & G5 & 836 & Brian Klaas & $\begin{array}{l}\text { American political scientist and columnist at } \\
\text { the Washington Post. He is an associate } \\
\text { professor in global politics at University } \\
\text { College London }\end{array}$ \\
\hline 6 & G6 & 453 & ABC News & Public news service in Australia \\
\hline 7 & G7 & 246 & The Associated Press & American not-for-profit news agency \\
\hline 8 & G8 & 159 & BBC News (World) & $\begin{array}{l}\text { International English-language pay television } \\
\text { network, operated under the } \mathrm{BBC}\end{array}$ \\
\hline 9 & G9 & 128 & $\begin{array}{l}\text { World Health } \\
\text { Organization (WHO) }\end{array}$ & $\begin{array}{l}\text { Specialized agency of the United Nations } \\
\text { responsible for international public health. }\end{array}$ \\
\hline 10 & G10 & 97 & $\begin{array}{l}\text { Tedros Adhanom } \\
\text { Ghebreyesus }\end{array}$ & $\begin{array}{l}\text { Director general of the World Health } \\
\text { Organization }\end{array}$ \\
\hline
\end{tabular}

Table 5. The top 10 key players in Italy

\begin{tabular}{|c|c|c|c|c|}
\hline & Label & ID & Name & Description \\
\hline 1 & G1 & 2,717 & ABC News & $\begin{array}{l}\text { The news division of American Broadcasting } \\
\text { Company broadcast network }\end{array}$ \\
\hline 2 & $\mathrm{G} 2$ & 1,542 & The Spectator Index & Online magazine website \\
\hline 3 & G3 & 1,446 & SkyNews & British free-to-air television news \\
\hline 4 & G4 & 545 & The Daily Beast & American news and opinion website \\
\hline 5 & G5 & 392 & NBC News NOW & Online streaming network from NBC News \\
\hline 6 & G6 & 391 & NBC News & American broadcast television network NBC \\
\hline 7 & G7 & 100 & Financial Times & International daily newspaper \\
\hline 8 & G8 & 94 & ABC News Live & $\begin{array}{l}\text { American 24-hour news network offered via } \\
\text { ABCNews.com }\end{array}$ \\
\hline 9 & G9 & 66 & $\begin{array}{l}\text { World Economic } \\
\text { Forum }\end{array}$ & $\begin{array}{l}\text { International Organization for Public-Private } \\
\text { Cooperation }\end{array}$ \\
\hline 10 & G10 & 60 & Donald Trump & The US president \\
\hline
\end{tabular}

central role in the largest group in the UK. Jeremy Farrar (N5) and the Office for National Statistics (N9) have a crucial effect on Group 2. People are interested in 'covid19', 'UK', and 'coronavirusoutbreak', followed by 'epidemic' and 'vaccine' (see Table 9). 
Table 6. The top 10 key players in Germany

\begin{tabular}{|c|c|c|c|c|}
\hline & Label & ID & Name & Description \\
\hline 1 & G1 & 12,423 & David Samadi & $\begin{array}{l}\text { Board-certified urologist and the former Chairman } \\
\text { of Urology and Chief of Robotic Surgery at } \\
\text { Lenox Hill Hospital }\end{array}$ \\
\hline 2 & G2 & 1,569 & $\begin{array}{l}\text { The Spectator } \\
\text { Index }\end{array}$ & Online magazine website \\
\hline 3 & G3 & 838 & Brian Klaas & $\begin{array}{l}\text { Political scientist and columnist at the Washington } \\
\text { Post. }\end{array}$ \\
\hline 4 & G4 & 677 & Bernie Sanders & United States Senator \\
\hline 5 & G5 & 104 & Financial Times & International daily newspaper \\
\hline 6 & G6 & 63 & The Economist & International weekly newspaper \\
\hline 7 & G7 & 53 & The Japan Times & $\begin{array}{l}\text { Japan's largest and oldest English-language daily } \\
\text { newspaper }\end{array}$ \\
\hline 8 & G8 & 41 & Daily Mail Online & British daily middle-market newspaper \\
\hline 9 & G9 & 38 & Max Roser & $\begin{array}{l}\text { economist, philosopher, and media critic for large } \\
\text { global problems }\end{array}$ \\
\hline 10 & G10 & 26 & Donald Trump & The US president \\
\hline
\end{tabular}

Table 7. The top 10 key players in France

\begin{tabular}{|c|c|c|c|c|}
\hline & Label & ID & Name & Description \\
\hline 1 & N1 & 2,615 & Conflits & $\begin{array}{l}\text { Global news media in France for politics, } \\
\text { terrorism, cyber security, health. }\end{array}$ \\
\hline 2 & G1 & 1,571 & $\begin{array}{l}\text { The Spectator } \\
\text { Index }\end{array}$ & Online magazine website \\
\hline 3 & G2 & 837 & Brian Klaas & $\begin{array}{l}\text { American political scientist and columnist at the } \\
\text { Washington Post. He is an associate professor in } \\
\text { global politics at University College London }\end{array}$ \\
\hline 4 & G3 & 500 & $\begin{array}{l}\text { Coronavirus } \\
\text { NEWSUN }\end{array}$ & News for COVID-19 \\
\hline 5 & G4 & 212 & Piyush Goyal & Minister of Commerce and Industry \\
\hline 6 & $\mathrm{~N} 2$ & 207 & Le Parisien Infog & $\begin{array}{l}\text { French daily newspaper covering both international } \\
\text { and national news in infographics }\end{array}$ \\
\hline 7 & $\mathrm{~N} 3$ & 203 & Le Parisien & $\begin{array}{l}\text { French daily newspaper covering both international } \\
\text { and national news }\end{array}$ \\
\hline 8 & N4 & 199 & Jean Messiha & $\begin{array}{l}\text { French economist, senior civil servant and } \\
\text { politician. He became Deputy Under-Secretary } \\
\text { for Management at the Ministry of Defence }\end{array}$ \\
\hline 9 & N5 & 199 & Ouest-France & $\begin{array}{l}\text { Daily French newspaper known for its emphasis on } \\
\text { both local and national news }\end{array}$ \\
\hline 10 & N6 & 164 & LesNews & $\begin{array}{l}\text { Since 2009, the latest information on Alert, Flash } \\
\text { info, Breaking news in French }\end{array}$ \\
\hline
\end{tabular}


Table 8. The top 10 key players in Sweden

\begin{tabular}{|c|c|c|c|c|}
\hline & Label & ID & Name & Description \\
\hline 1 & G1 & 378 & CBS News & American television and radio service CBS \\
\hline 2 & G2 & 282 & YouGov & $\begin{array}{l}\text { International Internet-based market research and data } \\
\text { analytics website }\end{array}$ \\
\hline 3 & G3 & 233 & Bloomberg & International news agency \\
\hline 4 & G4 & 216 & Zerohedge & $\begin{array}{l}\text { News site for presenting staff-written articles and } \\
\text { aggregating news and opinions from external } \\
\text { sources. }\end{array}$ \\
\hline 5 & G5 & 177 & Karol Sikora & Founder and medical director of Rutherford Health \\
\hline 6 & G6 & 139 & Mike Galsworthy & Co-founder of Scientists for EU and Healthier IN \\
\hline 7 & G7 & 114 & STAT & American health-oriented news website \\
\hline 8 & G8 & 59 & Donald Trump & The US president \\
\hline 9 & G9 & 52 & $\begin{array}{l}\text { Bloomberg } \\
\text { Politics }\end{array}$ & Political news, data, analysis, and video \\
\hline 10 & G10 & 50 & Patrick Vallance & British physician, scientist, and clinical pharmacologist \\
\hline
\end{tabular}

In the Spanish networks, the most noticeable finding is that Spain is the only country that has WHO and Tedros Adhanom Ghebreyesus, who is the director general of the World Health Organization (WHO: ninth and Tedros Adhanom Ghebreyesus: tenth) (see Table 4). The result shows that the WHO only plays an important role in social networks for COVID-19 in Spain. In addition, channels of CNN, which is the American news-based pay television channel, play a significant role in social networks of Spain. For instance, CNN International ranks first, and CNN places third. Other news media exert a critical impact on the social networks of COVID-19. For instance, The Spectator Index, which is the online magazine website, takes second, and Reuters, the international news company, ranks fourth. ABC News, which is the American Broadcasting Company broadcast network, takes sixth, The Associated Press, which is the American news agency, ranks seventh, and BBC World News, which is the operational business division of the British Broadcasting Corporation, places eighth.

Nodes show more dispersed patterns, whereas key players are still concentrated in the central part of the circle (see Figure 4). Nodes in Spain tend to be concentrated as a circle in the groups (see Figure 5). CNN International (G1) is located in the centre of group 1, and The Spectator Index (G2) plays a crucial role in group 2. All key players are placed within group 10 except for the World Health Organization (G9) and Tedros Adhanom Ghebreyesus (G10). G9 and G10 exert a critical impact on the same group (group 14), and this result is reasonable since Tedros Adhanom Ghebreyesus is the Director General of the World Health Organization. People focus on 'Spain', 'covid19', and 'nato', ahead of 'sciencesurprises' and 'china'.

In the Italian networks, the most significant finding is that news media play the most important role in the social networks for COVID-19 among all countries (see Table 5). For instance, eight out of the top 10 key players are news media, and they 


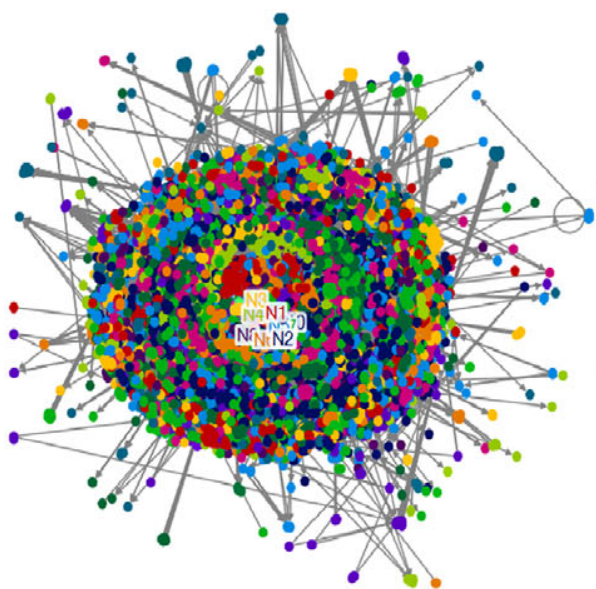

[UK]

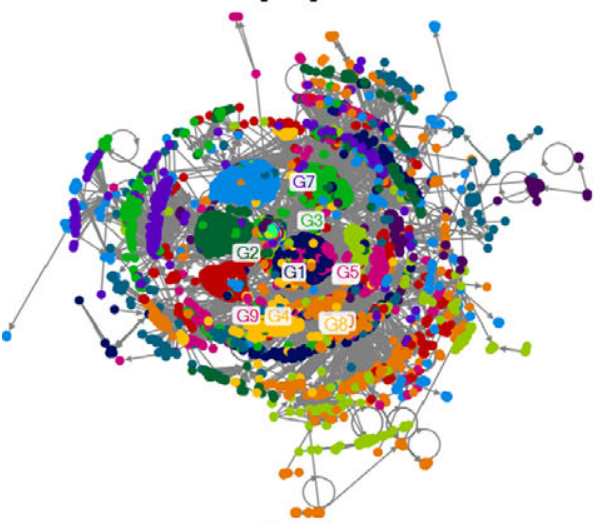

[ltaly]

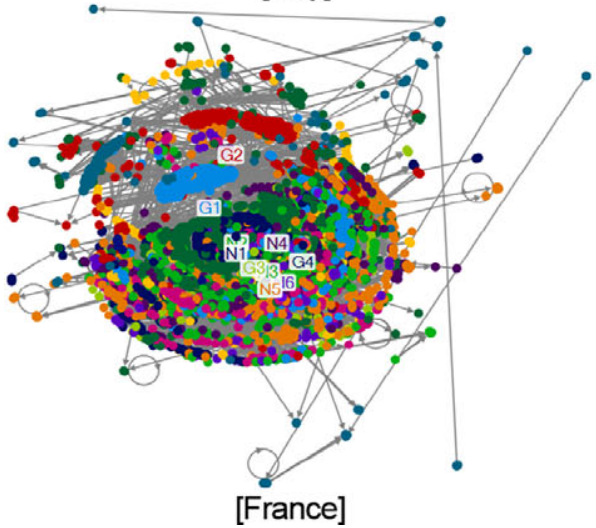

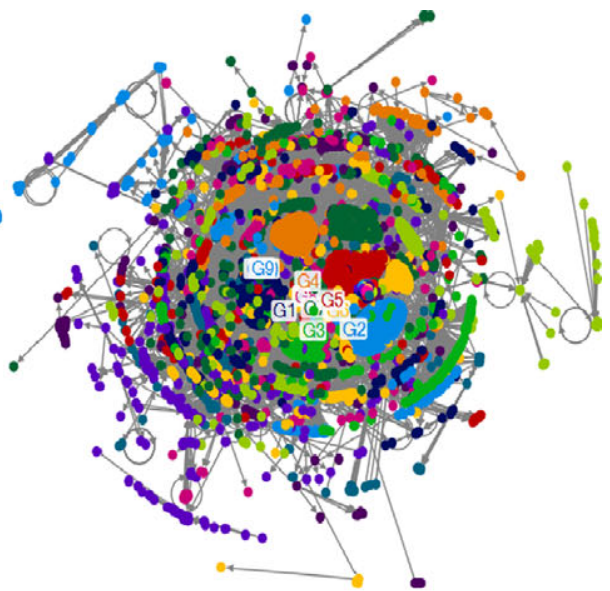

[Spain]

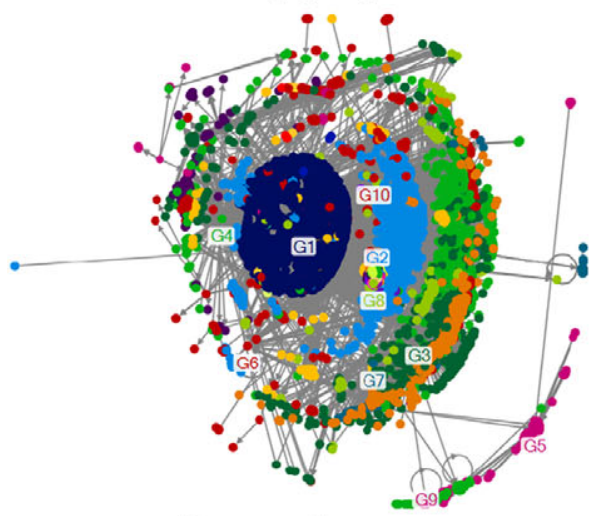

[Germany]

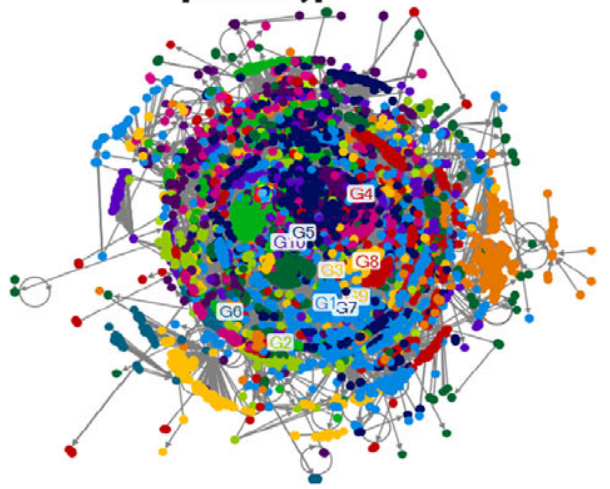

[Sweden]

Figure 4. Social networks for the typical case

rank from first to eighth. For example, ABC News, which is the news division of American Broadcasting Company broadcast network, ranks first, and The Spectator Index places second. SkyNews, which is the British free-to-air television 


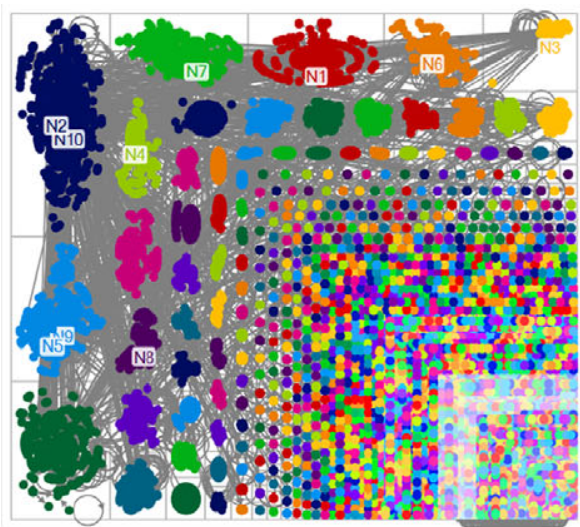

[UK]

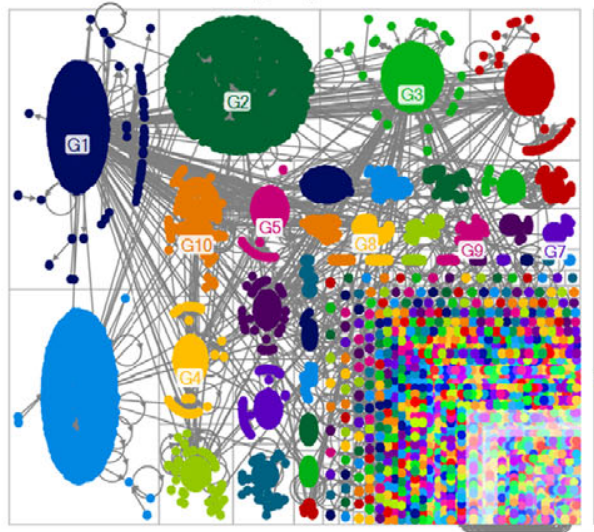

[ltaly]

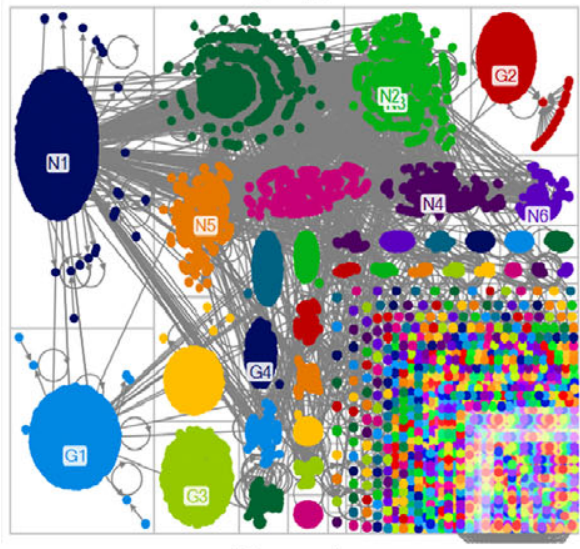

[France]

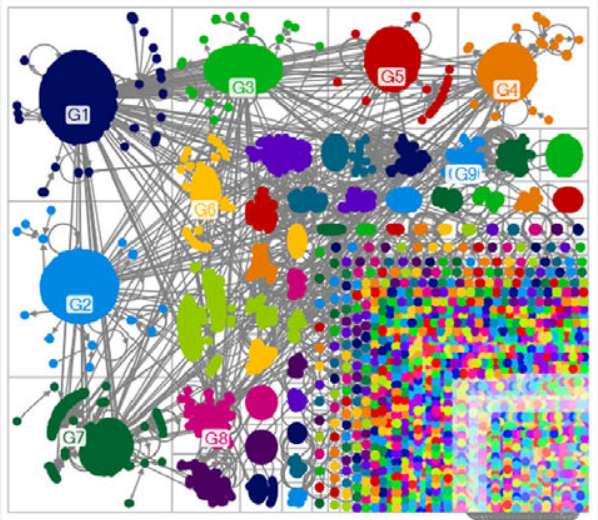

[Spain]

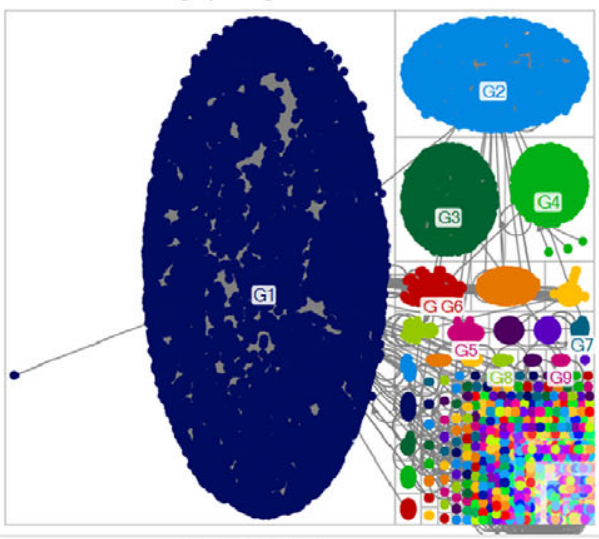

[Germany]

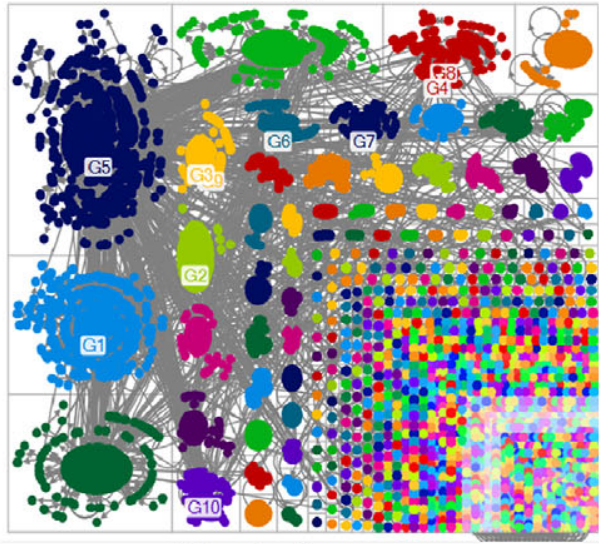

[Sweden]

Figure 5. Social networks according to groups 
news, takes third, and The Daily Beast, which is the American news and opinion website, places fourth. NBC News NOW and NBC News, which are the channels of the American broadcast television network NBC, rank fifth and sixth, respectively.

Nodes show the most dispersed patterns, and ABC News (G1) is located in the centre of social networks (see Figure 4). All key players in Italy have their independent group except for NBC News NOW (G5) and NBC News (G6) (see Figure 5). They are located in the same group (group 9) since they are the channels of NBC News. ABC News (G1) plays an important role in group 1. Italy is the only country that has no key player in group 2 among six countries. Instead, The Spectator Index (G2) exerts a crucial impact on group 3. People add a hashtag to 'covid19', 'beatcovid19', 'Italy', 'oceans', and 'china' (see Table 9).

In the German networks, the critical finding is that people play an essential role in social networks for COVID-19 (see Table 6). For example, David Samadi, who is the board-certified urologist and the former chairman of urology and chief of robotic surgery at Lenox Hill Hospital, ranks first. Brian Klaas, who is the political scientist and columnist at the Washington Post, places third. Bernie Sanders, who is a US senator, takes fourth, and Max Roser, who is an economist, philosopher and media critic, and who focuses on large global problems, ranks ninth. Donald Trump, the US president, takes tenth.

Nodes reveal some layers, and key players exhibit the most diffuse patterns. For example, Financial Times (G5) and Max Roser (G9) are located in the outside of the main networks (see Figure 4). Nodes in Germany are heavily concentrated in group 1 (see Figure 5). In addition, Germany shows the least communication networks across the groups. People in Germany tend to communicate with each other within the groups. David Samadi (G1), The Spectator Index (G2), Brian Klaas (G3), and Bernie Sanders (G4) play important roles in group 1, group 2, group 3, and group 4, respectively. People use hashtag 'Germany', 'covid19' and 'china', followed by 'schools' and 'studies' (see Table 9).

In the French networks, the critical finding is that national key players have a more significant effect on social networks for COVID-19 than global key players (see Table 7). For example, France has six national key players, which is two more than global key players (four). To be specific, Conflits, which is the global news media in France for politics, terrorism, cyber security and health, ranks first. Le Parisien Infog (infographics) and Le Parisien, which are the French daily newspapers covering both international and national news, place sixth and seventh, respectively. Jean Messiha who is the French economist, senior civil servant and politician ranks eighth. Ouest-France, which is the daily French newspaper known for its emphasis on both local and national news, places ninth. LesNews, which is the latest information on Alert, Flash information, Breaking news in French, takes tenth.

Nodes are highly located in the South side of the circle, and key players are also placed in that part except for The Spectator Index (G2) (see Figure 4). Nodes in group 1 in France actively communicate with each other, not only within the group but also across groups (see Figure 5). Conflits (N1) has a high influence on the largest 
Table 9. Hashtag analysis

\begin{tabular}{|c|c|c|c|c|c|c|c|c|c|c|c|c|}
\hline \multicolumn{3}{|c|}{ UK } & \multicolumn{2}{|l|}{ Spain } & \multicolumn{2}{|l|}{ Italy } & \multicolumn{2}{|c|}{ Germany } & \multicolumn{2}{|c|}{ France } & \multicolumn{2}{|l|}{ Sweden } \\
\hline & Hashtags & $\overline{\text { Count }}$ & $\overline{\text { Hashtags }}$ & $\overline{\text { Count }}$ & Hashtags & $\overline{\text { Count }}$ & $\overline{\text { Hashtags }}$ & $\overline{\text { Count }}$ & Hashtags & $\overline{\text { Count }}$ & Hashtags & Count \\
\hline & covid19 & 11,364 & spain & 588 & covid19 & 1849 & germany & 172 & hee & 3228 & covid19 & 313 \\
\hline 2 & uk & 917 & covid19 & 460 & beatcovid19 & 391 & covid19 & 90 & coronavirus & 1939 & sweden & 256 \\
\hline 3 & coronavirusoutbreak & 248 & nato & 102 & italy & 276 & china & 43 & masque & 1879 & fakenewsmedian & 204 \\
\hline 4 & epidemic & 239 & sciencesurprises & 102 & oceans & 49 & schools & 43 & encuesta & 500 & herdimmunity & 55 \\
\hline 5 & vaccine & 228 & china & 64 & china & 44 & studies & 42 & caumes & 385 & lockdown & 45 \\
\hline
\end{tabular}


group (group 1), and The Spectator Index (G1) shows an important impact on the second-largest group (group 2). All key players have their independent group except for Le Parisien Infog (N2) and Le Parisien (N3). People have interests in 'France', 'coronavirus', and 'masque', which is a mask in English, and 'encuesta', which is a survey in English (see Table 9). The next hashtag is 'caumes', which is a department in northwest France named after the Mayenne River. For the sake of readers, the department of Mayenne in northwest France (Pays de la Loire) was on high vulnerability alert after new cases of Covid-19 were reported. The local authorities required masks to be mandatory in public. Mayenne was the first department in mainland France to be classed as a high vulnerability situation.

In the Swedish networks, websites and founders of health institutes, which do not rank in other countries, play a crucial role in social networks for COVID-19 (see Table 8). For instance, YouGov, which is the international internet-based market research and data analytics website, ranks second. Zerohedge, which is the news site for presenting staff-written articles and aggregating news and opinions from external sources, places fourth. STAT, which is the American health-oriented news website, takes seventh. Karol Sikora, who is the founder and medical director of Rutherford Health, ranks fifth, and Mike Galsworthy, who is the co-founder of Scientists for EU and Healthier IN, places sixth.

Nodes show a large circle, and key players reveal distributed patterns (see Figure 4). Nodes in Sweden exhibit active communication networks across the groups (see Figure 5). Karol Sikora (G5) plays an important role in group 1, and CBS News (G1) shows the central role in group 2. Zerohedge (G4) and Donald Trump (G8) have the same group (group 5), and Bloomberg and Bloomberg Politics are located in the same group as well (group 7). People type a hashtag 'covid1', 'Sweden', 'fakenewsmedianarrative', ahead of 'herdimmunity' and 'lockdown'. Herd immunity occurs when the vast majority of people become immune to COVID-19, causing the spread of disease from person to person to become unlikely. As a result, it is possible the whole country becomes protected (see Table 9).

\section{Discussion}

COVID-19 has become the most important issue across the world since 2020 . Understanding the COVID-19 pandemic has become one of the top priorities for governments and Centres for Disease Control and Prevention in order to protect their citizens' lives. Against this background, this study sheds new light on understanding different social networks for COVID-19 across various European countries by employing SNA for Twitter.

This study has some important implications. It highlights how people develop their social networks to get important news and data, based on SNA and big data analyses. Scholars could develop theories for a new virus regarding social networks and big data, between the entities, the closeness of their association, the strength of ties, the structural holes or bridges, and the nature of directionality of interaction 
(Kar and Dwivedi, 2020; Zuo et al., 2020). Governments and Centres for Disease Control and Prevention would be able to understand social networks for COVID19 to aid them in spreading important news and information to the public in a timely manner.

Next, this study finds that people build different social networks for COVID-19 on Twitter according to countries and groups. The findings of this study support the results of the prior literature (see, for example, Rufai and Bunce, 2020; Yum, 2020b; Yum, 2021). For instance, Rufai and Bunce (2020) find that Twitter may represent a powerful tool for Group of Seven (G7) world leaders in response to COVID-19. This study and the prior studies suggest that governments and health practitioners can rapidly communicate public health information with citizens by understanding the social networks of SNS.

Third, this study suggests how people can find reliable information resources and important Twitter users for COVID-19 by considering the top public key players based on the in-degree centrality. Prior studies highlight that social media has become a home ground for misinformation during the COVID-19 pandemic (see, for example, Kouzy et al., 2020; Rosenberg et al., 2020; Shahi et al., 2021). For example, 153 tweets (24.8\%) include misinformation, and 107 (17.4\%) include unverifiable information regarding the COVID-19 epidemic based on 673 tweets of the Twitter social media platform on 27 February 2020 (Kouzy et al., 2020). Therefore, this study provides important implications for social media and communication research.

This article suggests some crucial implications as follows: first, governments and decision makers should try to understand the characteristics of social networks in their country, since countries show different network systems for COVID-19. They should also explore the national and global key players of COVID-19 for their country in order to spread relevant information on COVID-19 as soon as possible. Second, governments and centres for disease control should investigate social networks according to groups, since people show different communication networks among groups according to countries. Third, heads of government should investigate the interests of people regarding COVID-19 because the public are interested in various topics according to countries. Exploring Twitter would be one of the most useful ways to understand the current interests and needs from governments to citizens.

\section{Conclusions}

COVID-19 is considered the worst disease so far in the twenty-first century. Developing COVID-19 policies has become one of the most important tasks for governments and decision makers. In order to release valuable information on COVID19 and to deliver important news to the public on time, understanding social networks for COVID is necessary. In this sense, this study sheds new light on online communication systems for COVID-19 by employing SNA for Twitter across six countries in Europe. 
This study finds some significant results as follows: first, European countries show different characteristics for social networks regarding COVID-19. For example, the UK has only national key players, France shows a majority of national key players, and other countries have all global key players. Donald Trump played an important role in the social networks of Italy (tenth), Germany (tenth), and Sweden (eighth), while he was the US president. To be specific, the UK has many important government key players. Spain is the only country in which the WHO plays an important role in social networks for COVID. Italy has news media as the most important key players. In contrast, Germany shows people as the most crucial key players. France exhibits national key players more than global key players. Sweden has some key players, such as websites and founders of health institutes, which do not rank in other countries.

Second, European countries also demonstrate different social networks of groups. For example, the UK shows the most active communications across groups. In addition, the UK is the only country that has all top key players within group 10 . In contrast, Germany shows the least communication networks across the groups, and nodes are heavily concentrated in group 1. Finally, European countries reveal highly different interests for COVID-19. For example, the UK is more interested in the epidemic and vaccines, Germany focuses on schools and studies, and Sweden cares more about herd immunity and lockdown.

\section{References}

Aguinis H and Edwards JR (2014) Methodological wishes for the next decade and how to make wishes come true. Journal of Management Studies 51(1), 143-174.

Ahmad AR and Murad HR (2020) The impact of social media on panic during the COVID-19 pandemic in Iraqi Kurdistan: online questionnaire study. Journal of Medical Internet Research 22(5), e19556.

Block P, Hoffman M, Raabe IJ, Dowd JB, Rahal C, Kashyap R and Mills MC (2020) Social network-based distancing strategies to flatten the COVID-19 curve in a post-lockdown world. Nature Human Behaviour 4(6), 588-596.

Bonaccorsi G, Pierri F, Cinelli M, Flori A, Galeazzi A, Porcelli F . . Pammolli F (2020) Economic and social consequences of human mobility restrictions under COVID-19. Proceedings of the National Academy of Sciences 117(27), 15530 15535.

Bonchi F, Castillo C, Gionis A and Jaimes A (2011) Social network analysis and mining for business applications. ACM Transactions on Intelligent Systems and Technology (TIST) 2(3), 1-37.

Borgatti SP and Everett MG (1992) Notions of position in social network analysis. Sociological Methodology, 1-35.

Borges do Nascimento IJ, Cacic N, Abdulazeem HM, von Groote TC, Jayarajah U, Weerasekara I . . Carvas Junior N (2020) Novel coronavirus infection (COVID19) in humans: a scoping review and meta-analysis. Journal of Clinical Medicine 9(4), doi.org/10.3390/jcm9040941.

Brodin P (2020) Why is COVID-19 so mild in children? Acta Paediatrica 109(6), 1082-1083. 
Burt R (1978) Applied network analysis: An overview. Sociological Methods Research 7(2), 123-130.

Campbell AM (2020) An increasing risk of family violence during the Covid-19 pandemic: Strengthening community collaborations to save lives. Forensic Science International: Reports, 100089.

Cao Y, Li Q, Chen J, Guo X, Miao C, Yang H ... Li L (2020) Hospital emergency management plan during the COVID-19 epidemic. Academic Emergency Medicine 27(4), 309-311.

Chakraborty I and Maity P (2020) COVID-19 outbreak: Migration, effects on society, global environment and prevention. Science of the Total Environment 138882.

Chakraborty A and Kar AK (2021) How did COVID-19 impact working professionals - a typology of impacts focused on education sector. International Journal of Information and Learning Technology, https://doi.org/10.1108/IJILT-06-20200125

Chen S, Yang J, Yang W, Wang C and Bärnighausen T (2020) COVID-19 control in China during mass population movements at New Year. The Lancet 395(10226), 764-766.

Chen Q, Min C, Zhang W, Wang G, Ma X and Evans R (2020) Unpacking the black box: How to promote citizen engagement through government social media during the COVID-19 crisis. Computers in Human Behavior 110, 106380.

Chow-White P, Struve S, Lusoli A, Lesage F, Saraf N and Oldring A (2018) 'Warren Buffet is my cousin': shaping public understanding of big data biotechnology, direct-to-consumer genomics, and $23 \mathrm{andMe}$ on Twitter. Information, Communication \& Society 21(3), 448-464.

Cinelli M, Quattrociocchi W, Galeazzi A, Valensise CM, Brugnoli E, Schmidt AL ... Scala A (2020) The covid-19 social media infodemic. Scientific Reports 10(1), $1-10$.

Collaborative C (2020) Elective surgery cancellations due to the COVID-19 pandemic: global predictive modelling to inform surgical recovery plans. British Journal of Surgery DOI: 10.1002/bjs.11746.

Cuello-Garcia C, Pérez-Gaxiola G and van Amelsvoort L (2020) Social media can have an impact on how we manage and investigate the COVID-19 pandemic. Journal of Clinical Epidemiology 127, 198-201.

ECDC (2020) Communicable diseases threat report, 18 July 2020. ECDC: Sweden.

Ennett ST, Bauman KE, Hussong A, Faris R, Foshee VA, Cai L and DuRant RH (2006) The peer context of adolescent substance use: Findings from social network analysis. Journal of Research on Adolescence 16(2), 159-186.

European Centre for Disease Prevention and Control (2020a) COVID-19 Situation Update Worldwide. Sweden: European Centre for Disease Prevention and Control.

European Centre for Disease Prevention and Control (2020b) COVID-19 Surveillance Report Week 28. Sweden: European Centre for Disease Prevention and Control.

European Council (2020) COVID-19 Coronavirus Pandemic. Belgium: European Council.

Fang Y, Nie Y and Penny M (2020) Transmission dynamics of the COVID-19 outbreak and effectiveness of government interventions: A data-driven analysis. Journal of Medical Virology 92(6), 645-659.

Fernandes N (2020) Economic effects of coronavirus outbreak (COVID-19) on the world economy. Available at SSRN 3557504. 
Flaxman S, Mishra S, Gandy A, Unwin HJT, Mellan TA, Coupland H ... Monod M (2020) Estimating the effects of non-pharmaceutical interventions on COVID-19 in Europe. Nature https://doi.org/10.1038/s41586-020-2405-7.

Freeman LC (1978) Centrality in social networks conceptual clarification. Social Networks 1(3), 215-239.

Gao J, Zheng P, Jia Y, Chen H, Mao Y, Chen S . . Dai J (2020) Mental health problems and social media exposure during COVID-19 outbreak. Plos One 15(4), e 0231924.

Gayo-Avello D (2013) A meta-analysis of state-of-the-art electoral prediction from Twitter data. Social Science Computer Review 31(6), 649-679.

Grover V, Lindberg A, Benbasat I and Lyytinen K (2020) The perils and promises of big data research in information systems. Journal of the Association for Information Systems 21(2), 268-292

Grover P, Kar AK and Davies G (2018) 'Technology enabled Health' - insights from Twitter analytics with a socio-technical perspective. International Journal of Information Management 43, 85-97.

Hale T, Petherick A, Phillips T and Webster S (2020) Variation in government responses to COVID-19. Blavatnik School of Government Working Paper 1-23.

Hansen D, Shneiderman B and Smith MA (2010) Analyzing Social Media Networks with NodeXL: Insights from a Connected World. Massachusetts: Morgan Kaufmann.

Hollander JE and Carr BG (2020) Virtually perfect? Telemedicine for COVID-19. New England Journal of Medicine 382(18), 1679-1681.

Hung M, Lauren E, Hon ES, Birmingham WC, Xu J, Su S . . Lipsky MS (2020) Social network analysis of COVID-19 Sentiments: application of artificial intelligence. Journal of Medical Internet Research 22(8), e22590.

Hussain W (2020) Role of social media in covid-19 pandemic. The International Journal of Frontier Sciences 4(2), 59-60.

Jandrić P (2020) Postdigital research in the time of Covid-19. Postdigital Science and Education 1-6.

Jagals D and Van der Walt MS (2016) Exploiting metacognitive networks embedded in narrative focus group interviews using NodeXL. The Qualitative Report 21(10), $1868-1880$.

Kar AK (2020) What affects usage satisfaction in mobile payments? Modelling user generated content to develop the 'Digital service usage satisfaction model'. Information Systems Frontiers 1-21.

Kar AK and Dwivedi YK (2020) Theory building with big data-driven research Moving away from the 'What' towards the 'Why'. International Journal of Information Management 54, 102205.

Karami A, Bookstaver B, Nolan M and Bozorgi P (2021) Investigating diseases and chemicals in COVID-19 literature with text mining. International Journal of Information Management Data Insights 100016.

Kinross P, Suetens C, Dias JG, Alexakis L, Wijermans A, Colzani E and Monnet DL (2020) Rapidly increasing cumulative incidence of coronavirus disease (COVID19) in the European Union/European Economic Area and the United Kingdom, 1 January to 15 March 2020. Eurosurveillance 25(11), 2000285.

Koch J, Plattfaut R and Kregel I (2021) Looking for talent in times of crisis - the impact of the covid-19 pandemic on public sector job openings. International Journal of Information Management Data Insights 1(2), 100014. 
Kouzy R, Abi Jaoude J, Kraitem A, El Alam MB, Karam B, Adib E . . Baddour K (2020) Coronavirus goes viral: quantifying the COVID-19 misinformation epidemic on Twitter. Cureus 12(3), e7255.

Le TT, Andreadakis Z, Kumar A, Roman RG, Tollefsen S, Saville M and Mayhew S (2020) The COVID-19 vaccine development landscape. Nature Reviews Drug Discovery 19(5), 305-306.

Lechien JR, Chiesa-Estomba CM, De Siati DR, Horoi M, Le Bon SD, Rodriguez A ... Chekkoury-Idrissi Y (2020) Olfactory and gustatory dysfunctions as a clinical presentation of mild-to-moderate forms of the coronavirus disease (COVID-19): a multicenter European study. European Archives of Oto-Rhino-Laryngology 277, 2251-2261.

Li Y, Chandra Y and Kapucu N (2020) Crisis coordination and the role of social media in response to COVID-19 in Wuhan, China. The American Review of Public Administration 50(6-7), 698-705.

Liao Q, Yuan J, Dong M, Yang L, Fielding R and Lam WWT (2020) Public engagement and government responsiveness in the communications about COVID-19 during the early epidemic stage in China: infodemiology study on social media data. Journal of Medical Internet Research 22(5), e18796.

Lin Q, Zhao S, Gao D, Lou Y, Yang S, Musa SS ... He D (2020) A conceptual model for the outbreak of Coronavirus disease 2019 (COVID-19) in Wuhan, China with individual reaction and governmental action. International Journal of Infectious Diseases 93, 211-216.

Liu C, Zhou Q, Li Y, Garner LV, Watkins SP, Carter LJ ... Albaiu D (2020) Research and development on therapeutic agents and vaccines for COVID-19 and related human coronavirus diseases. ACS Central Science 6(3), 315-331.

Mizruchi MS (1994) Social network analysis: Recent achievements and current controversies. Acta Sociologica 37(4), 329-343.

Nambisan P, Luo Z, Kapoor A, Patrick TB and Cisler RA (2015) Social media, big data, and public health informatics: ruminating behavior of depression revealed through Twitter. In 2015 48th Hawaii International Conference on System Sciences, 2906-2913.

Nielsen BF, Simonsen L and Sneppen K (2021) COVID-19 superspreading suggests mitigation by social network modulation. Physical Review Letters 126(11), 118301.

Oliver N, Lepri B, Sterly H, Lambiotte R, Deletaille S, De Nadai M ... Colizza V (2020) Mobile phone data for informing public health actions across the COVID19 pandemic life cycle. DOI: $10.1126 /$ sciadv.abc0764.

Ramanathan K, Antognini D, Combes A, Paden M, Zakhary B, Ogino M ... Shekar K (2020) Planning and provision of ECMO services for severe ARDS during the COVID-19 pandemic and other outbreaks of emerging infectious diseases. The Lancet Respiratory Medicine 8(5), 518-526.

Rosenberg H, Syed S and Rezaie S (2020) The Twitter pandemic: the critical role of Twitter in the dissemination of medical information and misinformation during the COVID-19 pandemic. Canadian Journal of Emergency Medicine 22(4), 418-421.

Rufai SR and Bunce C (2020) World leaders' usage of Twitter in response to the COVID-19 pandemic: a content analysis. Journal of Public Health 42(3), 510-516.

Shahi GK, Dirkson A and Majchrzak TA (2021) An exploratory study of covid-19 misinformation on twitter. Online Social Networks and Media 22, 100104.

Shaker MS, Oppenheimer J, Grayson M, Stukus D, Hartog N, Hsieh EW ... Chan ES (2020) COVID-19: pandemic contingency planning for the allergy and 
immunology clinic. The Journal of Allergy and Clinical Immunology: In Practice 8(5), 1477-1488.

Sebastiani G, Massa M and Riboli E (2020) Covid-19 epidemic in Italy: evolution, projections and impact of government measures. European Journal of Epidemiology 35(4), 341-345.

Shereen MA, Khan S, Kazmi A, Bashir N and Siddique R (2020) COVID-19 infection: origin, transmission, and characteristics of human coronaviruses. Journal of Advanced Research 24, 91-98.

Shneiderman B and Dunne C (2012) Interactive network exploration to derive insights: filtering, clustering, grouping, and simplification. In International Symposium on Graph Drawing 2-18.

Shoenfeld Y (2020) Corona (COVID-19) time musings: our involvement in COVID19 pathogenesis, diagnosis, treatment and vaccine planning. Autoimmunity Reviews 19(6), 102538.

Streeter CL and Gillespie DF (1993) Social network analysis. Journal of Social Service Research 16(1-2), 201-222.

Yum S (2020a) Social network analysis for coronavirus (COVID-19) in the United States. Social Science Quarterly 101(4), 1642-1647.

Yum S (2020b) Network relationships of U.S. government health agencies in relation to the Covid-19 pandemic. Information Research 25(4), paper 883.

Yum S (2021) Informatics for COVID-19 in New York and California. Disaster Medicine and Public Health Preparedness 1-14.

Zuo MZ, Angelopoulos SA, Ou CX, Carol XC, Liu HL and Liang ZL (2020) Identifying dynamic competition in online marketplaces through consumers' clickstream data. Available at SSRN:https://doi.org/10.2139/ssrn.3598889.

\section{About the Author}

Seungil Yum is $\mathrm{PhD}$ at the University of Florida who is examining urban economics, economic development, transportation, culture, environment, big data analysis, social network analysis, and creativity. 